\title{
Correction to: Combination Treatment with an Antibody-Drug Conjugate (A1mcMMAF) Targeting the Oncofetal Glycoprotein 5T4 and Carboplatin Improves Survival in a Xenograft Model of Ovarian Cancer
}

\author{
Y. Louise Wan ${ }^{1}$ D $\cdot$ Puja Sapra ${ }^{2} \cdot$ James Bolton $^{3} \cdot$ Jia Xin Chua ${ }^{4} \cdot$ Lindy G. Durrant $^{4} \cdot$ Peter L. Stern $^{5}$
}

Published online: 3 October 2019

(c) The Author(s) 2019

\section{Correction to: Targeted Oncology (2019) 14:465-477 https://doi.org/10.1007/s11523-019-00650-8}

The article Combination Treatment with an Antibody-Drug Conjugate (A1mcMMAF) Targeting the Oncofetal Glycoprotein 5T4 and Carboplatin Improves Survival in a Xenograft Model of Ovarian Cancer, written by Y. Louise Wan, Puja Sapra, James Bolton, Jia Xin Chua, Lindy G. Durrant and Peter L. Stern, was originally published under a CC BY-NC 4.0 license, but has now been made available under a CC BY 4.0 license. The article is forthwith distributed under a Creative Commons Attribution 4.0 International License (https://creativecommons.org/licenses/by/4.0/), which permits use, sharing, adaptation, distribution and reproduction in any medium or format, as long as you give appropriate credit to the original author(s) and the source, provide a link to the Creative Commons licence, and indicate if changes were made. The PDF and HTML versions of the paper have been modified accordingly.

The original article has been corrected.

Open Access This article is distributed under the terms of the Creative Commons Attribution 4.0 International License (http://creativeco mmons.org/licenses/by/4.0/), which permits unrestricted use, distribution, and reproduction in any medium, provided you give appropriate credit to the original author(s) and the source, provide a link to the Creative Commons license, and indicate if changes were made.

The original article can be found online at https://doi.org/10.1007/ s11523-019-00650-8.

Peter L. Stern

Peter.Stern@cruk.manchester.ac.uk

1 Division of Cancer Sciences, School of Medical Sciences, Faculty of Biology, Medicine and Health, The University of Manchester, 5th Floor Research, St Mary's Hospital, Oxford Road, Manchester M13 9WL, UK

2 Oncology Research and Development, Pfizer Inc., 401 N. Middletown Road, Pearl River, NY 10954, USA

3 Department of Histopathology, Manchester University NHS Foundation Trust, Oxford Road, Manchester M13 9WL, UK

4 Academic Clinical Oncology, The University of Nottingham, City Hospital Campus, Hucknall Road, Nottingham NG5 1PB, UK

5 Manchester Cancer Research Centre, Division of Cancer Sciences, School of Medical Sciences, Faculty of Biology, Medicine and Health, University of Manchester, Wilmslow Road, Manchester M20 4BX, UK 